SAKAI SAMBAYAN — Jurnal Pengabdian kepada Masyarakat

\title{
PELATIHAN PEMBUATAN KOMPOSIT KARET/KARBON HITAM KEPADA PETANI KARET DI DESA KOTAWAI, KECAMATAN KASUI, KABUPATEN WAY KANAN, LAMPUNG
}

\author{
Shirley Savetlana*, Irza Sukmana, Nafrizal \\ Jurusan Teknik Mesin Universitas Lampung, Bandar Lampung \\ Jl. Prof. Sumantri Brojonegoro No.1 Bandar Lampung 35145 \\ Penulis Korespodensi : shirley.savetlana@eng.unila.ac.id
}

\begin{abstract}
Abstrak
Daerah Lampung pada umumnya adalah daerah perkebunan. Salah satunya adalah perkebunan karet. Dalam kurun waktu beberapa tahun terakhir, harga karet nasional turun secara signifikan. Untuk menghadapai hal ini perlu dilakukannya langkah -langkah untuk meningkatkan nilai ekonomis karet. Teknologi material terus berkembang antara lain adalah teknologi material komposit. Komposit merupakan material yang dibentuk dari pencampuran dua atau lebih material - material teknik seperti logam, polimer, elastomer, kaca dan keramik. Komposit. Teknologi komposit dapat dipakai untuk meningkatkan nilai ekonomis karet. Komposit dibuat dengan mencampurkan karet alam dalam hal ini lateks dengan karbon hitam. Karbon hitam dapat meningkatkan sifat-sifat mekanik karet alam sehingga dapat digunakan untuk aplikasi pada produk yang lebih beragam.

Pelatihan pembuatan komposit karet alam karbon hitam didahului dengan penyampaian materi mengenai bahan teknik. Selanjutnya diberikan penjelasan mengenai cara pembuatan komposit. Kegiatan diikuti dengan demonstrasi pembuatan komposit. Pembuatan komposit karet alam/ karbon hitam atau sering disebut kompon dirancang untuk menggunakan bahan-bahan yang tidak terlalu mahal. Bahan-bahan untuk membuat komposit karet alam/karbon hitam antara lain lateks, karbon hitam, sulfur dan asam formiat atau asam semut. Alat alat yang digunakan antara lain mesin press dan mesin pemanas. Cara pembuatan dilakukan dengan pencampuran, pengepresan dan pemanasan.
\end{abstract}

Kata kunci: karet, koagulan, asam formiat, karbon hitam, komposit

\section{Pendahuluan}

Provinsi Lampung mempunyai area perkebunan karet yang cukup luas yaitu 50.614 hektar. Perkebunan karet tersebut terdiri dari $79 \%$ merupakan perkebunan karet rakyat. 10\% dikelola perusahaan besar seperti Perkebunan Nusantara dan $11 \%$ dikelola perusahaan besar swasta.

Petani memanen cairan karet dari pohon yang disebut lateks. Lateks yang didapat dari pohon karet hanya diolah seadanya. Misalnya untuk menggumpalkan lateks dengan cepat petani menggunakan asam format. Jika ingin lebih menghemat biaya petani mengganti asam format dengan tawas. Campuran tersebut didiamkan selama beberapa hari kemudian karet yang telah menggumpal dijual langsung kepada pengepul. Jika waktu penyimpanan karet lebih singkat maka harga jual karet kepada pengepul akan menjadi lebih murah lagi. Karet tersebut kemudian akan dijual oleh pengepul ke pabrik pengelohan karet untuk diolah menjadi karet setengah jadi sebelum akhirnya di jual kepabrik-pabrik pengolahan karet menjadi benda jadi. Sampai saat ini Lampung memiliki satu pabrik pengolahan karet di Kecamatan Menggala Timur, Kabupaten Tulangbawang.

Indonesia mengekspor karet dalam bentuk karet alam mentah. Nilai ekonomis karet mentah ini rendah sehingga nilai ekspor kita dalam jumlah yang besar tapi bernilai rendah. Hal ini menuntut adanya pengolahan karet alam mentah menjadi material yang lebih bernilai tinggi didalam negeri sehingga nilai ekspor meningkat.

Teknologi komposit telah berkembang pesat. Isu pemanasan global dan kelestarian lingkungan serta material terbarukan telah mengarahkan penelitian bidang komposit ke material komposit berbasis bahan alami. Teknologi komposit dapat digunakan untuk membuat bahan komposit berbahan dasar karet. Pemanfaatan teknologi ini memberikan peluang untuk peningkatan nilai ekonomis karet alam Lampung. Hal ini akan 
meningkatkan nilai ekspor karet alam dalam bentuk benda jadi dibandingkan jika tanpa di olah Indonesia hanya mengekspor karet alam mentah dengan nilai jual yang sangat rendah.

Saat ini harga karet pada tingkat petani sangat rendah sehingga tidak dapat mencukupi kebutuhan para petani. Rendahnya harga karet salah satunya disebabkan kualitas karet yang rendah. Pengetahuan para petani yang masih terbatas mengenai pengolahan karet dari mulai tahap pengambilan karet sampai menjadikan karet gumpal untuk dijual ke pengepul.

Pengolahan karet dari lateks menjadi karet gumpal untuk dapat dijual ke pengepul karet masih sangat sederhana. Petani karet masih mengandalkan tata cara tradisional yang dilakukan secara turun temurun. Misalnya kurangnya kajian mengenai perbandingan yang tepat untuk banyaknya zat pengumpal dan berapa lama waktu penyimpanan karet alam sebelum karet alam tersebut siap untuk dijual. Juga masih kurangnya kajian mengenai efek dari pengolahan awal tersebut terhadap sifat-sifat mekanik karet alam. Lebih jauh masih kurangnya peningkatan nilai ekonomis karet alam menjadi material yang lebih bernilai ekonomi tinggi seperti untuk bahan dasar komposit.

Tujuan dari kegiatan pengabdian ini adalah memberikan pemahaman kepada siswa pramuka sekabupaten way kanan yang merupakan puteraputeri petani karet cara mengolah karet alam agar mempunyai kualitas yang baik. Selanjutnya juga memgajarkan kepada petani bagaimana cara membuat komposit berbahan dasar karet alam.

Manfaat dari kegiatan ini adalah bertambahnya pengetahuan para siswa dan petani karet tentang mutu karet yang baik, para siswa dan petani mengenal ilmu komposit. Para siswa dan petani dapat membuat komposit berbahan dasar karet. Terbukanya wawasan para siswa dan petani karet mengenai pengembangan karet menjadi material komposit dan meningkatnya pendapatan para petani karet dengan pengetahuan pengolahan karet mentah dari kegiatan ini.

Karet alam mempunyai sifat antara lain memiliki daya elastisitas yang tinggi, daya aus tinggi, tidak mudah panas dan ketahanan terhadap retakan tinggi serta dapat diperbaharui. Sementara karet sintetis mempunyai keunggulan antara lain tahan terhadap bahan-bahan kimia. Jenis- jenis karet alam adalah:
Bahan karet yang didapat dari lateks kebun dari pohon Hevea Brasiliensis. Ada empat macam yaitu lateks kebun, sheet angin, slab tipis dan lump segar.Dasar dari pembagian itu adalah ukuran, kandungan kotoran, kadar air dan dimensi.

Jenis-jenis produk karet yaitu: Ribbeb Smoke Sheet (RSS), crepe, karet bongkah, karet spesifikasi, tyre rubber dan karet reklaim.

Ribbeb Smoke Sheet (RSS), jenis ini berupa lembaran dan diasapkan. RSS digolongkan berdasarkan kadar air, kekuatan dan kebersihannya. Jenis karet alam konvensional lainnya dalah crepe., Lateks pekat adalah jenis karet yang berbentuk cairan pekat. Cairan ini digunakan untuk pembuatan karet tipis dan karet bermutu tinggi.

Karet yang telah dikeringkan dan berbentuk bongkahan. Standar mutu karet bongkah di Indonesia dinyatakan dalam Standar Indonesian Rubber (SIR).

Karet spesifikasi teknis atau crumb rubber. Karet alam dengan mutu khusus. Karet ini dipak dalam bongkah-bongkah kecil, berat dan ukurannya seragam dilengkapi sertifikat uji coba laboratorium.

Tyre rubber adalah karet yang diproduksi menjadi bahan setengah jadi sebelum dijadikan bahan untuk produk karet seperti ban.

Karet reklaim adalah bahan karet dari karet bekas. Karet bekas yang merupakan scrap yang sudah divulkanisir. Karet reklaim baik digunakan sebagai campuran. Produk karet reklim lebih kaku, tahan lama dan tahan terhadap bensin dan minyak dibandingkan karet yang baru dibuat. Kelemahan karet reklim adalah kurang ulet dan tidak tahan gesekan sehingga tidak dapat digunkan sebagai bahan ban.

Adapun alat dan bahan yang umumnya digunakan dalam pengolahan karet yaitu: pertama adalah mesin penggilingan, penggilingan dilakukan untuk membentuk lembaran karet dan mengurangi kadar air pada karet. Yang kedua adalah tanki atau bejana koagulasi. Tanki ini digunakan untuk penggumpalan lateks.Selanjutnya adalah rumah pengeringan, untuk karet crepe. Ketiga adalah rumah pengasapan. Rumah pengasapan digunakan untuk pengeringan karet sheet. Air digunakan untuk pengencera lateks, pembuatan larutan kimia, pencucian hasil dan untuk pendingin mesin. Bahanbahan pada pengolahan karet yaitu bahan pembeku, bahan pewarna dan vulkanisasi, katalis, pelunak dan pengisi. 
Untuk pembekuan lateks ada beberapa macam bahan kimia yang bisa digunakan yaitu asam semut atau asam format dan asam asetat atau asam cuka.

Bahan lain adalah bahan pewarna. Bahan vulkanisasi karet seperti belerang, peroksida organik dan radiasi sinar gamma.

Bahan pencepat reaksi atau katalis yaitu thiazol (MBT dan MBTS), guanidin (DPG dan DOTG), sulfenamida (CBS dan Santocure), dithiokarbamat (ZDC dan ZDCB), thiuram sulfida (TMTM dan TMTD). Selain itu di tambahkan pula bahan penggiat yaitu Seng Oksida dan asma stearat.

Bahan pelunak untuk memudahkan dalam pembentukan karet. Bahan pelunak yang digunakan antara lain minyak naftenik, nabati, aromatik, ter pinus, lilin parafin, faktis, damar dan bitumen. Bahan pengisi dibagi dua yaitu pengisi aktif yaitu untuk menguatkan karet dan bahan pengisi non aktif yaitu bahan yang ditujukan untuk menambah kekerasan dan kekakuan saja. Contoh bahan pengisi aktif adalah karbon hitam, silika, aluminium silikat dan magnesium silikat. Bahan pengisi non aktif yaitu karbon hitam, silika, aluminium silika dan magnesium silika (Setyamidjaja, 1993).

\section{Bahan dan Metode}

Alat dan bahan serta cara pelaksanaan kegiatan adalah sebagai berikut:

Bahan terdiri dari lateks, karbon hitam, sulfur asam formiat dan alkohol. Alat-alat utama yang dibutuhkan yaitu cetakan, mixer, alat press dan oven. Alat-alat bantu yang dibutuhkan yaitu kuas, semprotan, sarung tangan, aluminium foil dan lain-lain. Cara pembuatan komposit yaitu: bahan-bahan yang digunakan dalam pembuatan bahan uji ini ditimbang menggunakan timbangan digital. Karet alam cair atau (lateks kebun) dimasukan kedalam wadah untuk dimixer selama 2 menit. Masukkan karbon hitam ke dalam mesin mixer. Melakukan proses mixer hingga tercampur rata dengan lateks kebun dengan waktu percampuran selama 15 menit. Dalam percampuran lateks kebun dan karbon hitam dan dilakukan proses mixer selama 3 menit. Setelah karet alam cair dan karbon hitam tercampur rata maka proses percampuran dihentikan. Selanjutnya menyiapkan cetakan yang dilapisi dengan alumunium foil, kemudian masukkan campuran tersebut ke dalam cetakan.Komposit karet karbon hitam didapat setelah di diamkan dalam cetakan selama 24 jam. Selanjutnya dilakukan curing pada komposit karet tersebut (Purbaya dkk, 2018, Savetlana S dkk, 2017 dan Ali dkk, 2016).

Metode pelaksanaan kegiatan yaitu tahap persiapan, pelatihan, penyuluhan dan demonstrasi cara pembuatan komposit kepada para petani karet, dilanjutkan dengan evaluasi dan penulisan laporan. Terlebih dahulu dilakukan identifikasi masalah. Setelah permasalahan yang dihadapi oleh khalayak terindetifikasi, maka masalah tersebut dicarikan pemecahaannya dengan memberikan pelatihan yang dikombinasikan dengan dialog atau diskusi antara penyampai materi pelatihan dengan peserta dan mencontohkan secara langsung pemecahaan masalah tersebut.

Khalayak sasaran pada kegiatan pengabdian ini adalah para petani karet di Desa Kotawai, Kecamatan Kasui, Kabupaten Way Kanan, Lampung dan siswa-siswa pramuka tingkat SMU yang merupakan anak-anak petani karet utusan SMU sekabupaten Waykanan.

Metode yang digunakan dal;am kegiatan ini adalah pelatihan yang berisi tentang teori pengetahuan bahan, sifat-sifat bahan yang, teknogi bahan serta pengujian-pengujian mekanik bahan yang dilakukan di industri. Mensosialisasikan dengan membawa spesimen standar pengujian bahan dari beberapa macam jenis bahan serta memperagakan cara pengujian bahan.

\section{Hasil dan Pembahasan}

Dari hasil pre test terlihat rata-rata pemahaman peserta terhadap materi yang diberikan sangat kurang tentang bahan teknik seperti komposit. Hal ini disebabkan karena sebagian besar peserta tidak mempunyai pengetahuan dasar mengenai pengetahuan mekanika bahan dan kimia bahan. Setelah dilakukan pelatihan, dari data post tes dapat dilihat peningkatan pemahman yang signifikan. Pada tabel 1 dapat dilihat nilai pre test dan post test tentang pemahamam peserta terhadap materi sedangkan untuk melihat prosentase distribusi pemahaman peserta penyuluhan dapat dilihat pada tabel 2 .

Tabel 1. Hasil Pre Test dan Post test tentang pemahaman peserta terhadap materi diambil 9 sampel dari 79 .

\begin{tabular}{|l|l|c|c|}
\hline No & Peserta & Pre Test (\%) & Post Test (\%) \\
\hline 1 & Peserta 1 & 10 & 90 \\
\hline 2 & Peserta 2 & 10 & 70 \\
\hline 3 & Peserta 3 & 10 & 80 \\
\hline
\end{tabular}




\begin{tabular}{|l|l|l|l|}
\hline 4 & Peserta 4 & 10 & 70 \\
\hline 5 & Peserta 5 & 10 & 85 \\
\hline 6 & Peserta 6 & 10 & 70 \\
\hline 7 & Peserta 7 & 10 & 80 \\
\hline 8 & Peserta 8 & 10 & 70 \\
\hline 9 & Peserta 9 & 10 & 80 \\
\hline
\end{tabular}

Keterangan :

$0 \%-50 \%$ : Belum memahami

$50,1 \%-70 \%$ : Cukup memahami

$70,1 \%-100 \%$ : Sangat memahami

Tabel 2. Prosentase distribusi pemahaman peserta penyuluhan

\begin{tabular}{|c|c|c|c|}
\hline No & Kategori & $\begin{array}{c}\text { Pre Test } \\
(\%)\end{array}$ & $\begin{array}{c}\text { Post test } \\
(\%)\end{array}$ \\
\hline 1 & Belum memahami & 100 & 0 \\
\hline 2 & Cukup Memahami & 0 & 45 \\
\hline 3 & Sangat memahami & 0 & 55 \\
\hline
\end{tabular}

Dari kegiatan pelatihan pengujian bahan yang dilakukan ini dengan metode penyampaian materi, diskusi dan peragaaan cara pengujian dan bentuk specimen uji terlihat hasil yang cukup menggembirakan dari pemahaman peserta terhadap materi pelatihan yang diberikan.

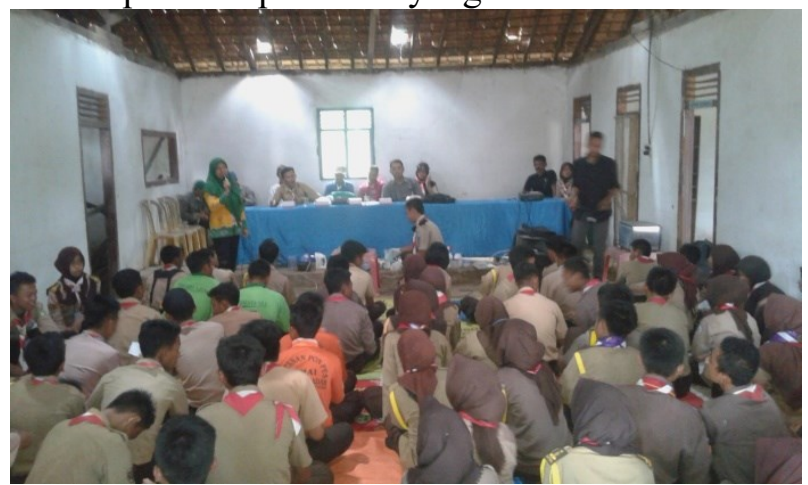

Gambar 1. Ceramah dari Dosen Teknik Mesin Unila mengenai pembuatan komposit karet/karbon hitam dengan bahan dasar karet

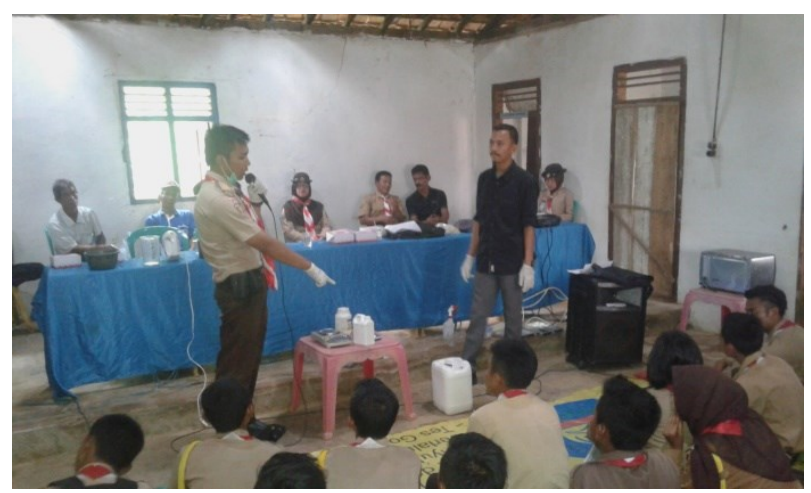

Gambar 2. Demonstrasi cara pembuatan komposit karet/karbon hitam oleh Mahasiswa Teknik Mesin Unila.
Hasil pelatihan dianggap cukup baik, namun hasil ini belum dapat menjadi patokan bahwa peserta dapat membuat komposit dengan baik di lapangan, butuh lebih dari satu kali latihan.

Setelah diadakan penyuluhan dan pelatihan serta dilakukan penilaian (post test) terlihat secara umum adanya peningkatan yang signifikan mengenai pemahaman peserta terhadap materi yang diberikan.

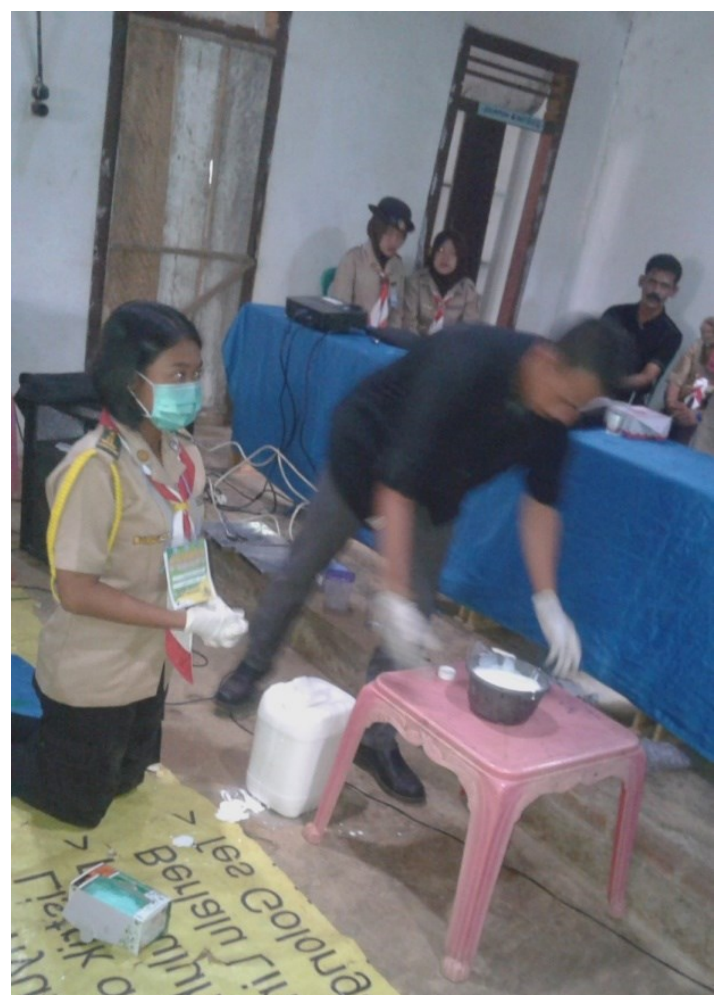

Gambar 3. Peserta kegiatan berlatih membuat komposit karet/karbon hitam.

\section{Kesimpulan}

1. Pembuatan komposit karet alam/karbon hitam dapat meningkatkan nilai ekonomis karet alam.

2. Pemahaman siswa tentang cara pembuatan komposit cukup baik terbukti dari hasil yang baik dari post test yang diberikan setelah pelatihan.

3. Pelatihan ini diharapkan dapat meningkatkan cakrawala berpikir siswa tentang teknologi pengetahuan bahan dan pengembangan produk karet alam.

\section{Ucapan Terima Kasih}

Kegiatan pengabdian ini dibiayai melalui dana DIPA FT Unila. Ucapan terima kasih juga disampaikan kepada Mahasiswa Teknik Mesin Universitas Lampung dan anggota pramuka utusan 
SMU sekabupaten Way-kanan atas dukungan dan partisipasinya dalam kegiatan pengabdian ini.

\section{Daftar Pustaka}

Ali, F., Astuti, W. N., \& Chairani, N. (2015). Pengaruh volume koagulan, waktu kontak dan temperatur pada koagulasi lateks dari kayu karet dan kulit kayu karet, Jurnal Teknik Kimia, 21(3), 27-35.
Purbaya, M., \& Vachlefi, A. (2018). Pengaruh koagulan konsentrasi rendah terhadap mutu dan harga bokar, Jurnal Standarisasi, 20(2), 139-146.

Setyamidjaja. (1993). karet budidaya dan pengolahannya, Kanisius, Jakarta

S Savetlana, Zulhendri, I Sukmana and F A Saputra. (2017). Material Science and Engineering, 223, 1-9. 